\title{
Peningkatan Nilai Kekerasan pada Bucket Teeth Excavator dengan Metode Pack Carburizing dan Media Quenching Oli SAE 20W-50 Serta Cangkang Kerang sebagai Energizer
}

\author{
Athanasius Priharyoto Bayuseno ${ }^{a}$, Dipo Adi Negoro ${ }^{\text {b, }}$ * \\ aDosen Departemen Teknik Mesin, Fakultas Teknik, Universitas Diponegoro \\ ${ }^{\mathrm{b}}$ Mahasiswa Program Studi S1, Departemen Teknik Mesin, Fakultas Teknik, Universitas Diponegoro \\ Jl. Prof. Sudharto, SH., Tembalang-Semarang 50275, Telp. +62247460059 \\ *E-mail: adi.dipo.negoro@gmail.com
}

\begin{abstract}
In an excavator, the end of the bucket that acts like claws is called bucket teeth. Bucket teeth are one of the most likely parts to be fail when the excavator is being used. To combat the failure, an increase in mechanical properties was performed especially for the surface hardness by pack carburizing. Carburizing pack is a type of carburizing in which a surface hardening process by adding carbon elements was performed by diffusion at temperature of $950^{\circ} \mathrm{C}$ with variations in holding time of 2.4 and 6 hours. Additionally variations in shellfish powder, which acts as an energizer, of 30, 40 and $50 w t \%$ were selected. After pack carburizing, the bucket teeth were quenched with SAE $20 \mathrm{~W}-50$ oil media to increase the hardness value. After that, testing of hardness, microstructure, and chemical composition of the samples were carried out to compare the properties before and after the carburizing pack process. The results showed that there was an increase in the value of hardness along with the amount of carbon content, where the highest hardness occurred in the variation of $70 \% \mathrm{C}$ $30 \%$ shellfish powder with a 4 hour holding time of 84.9 HRA. The carbon element diffusing into the material increased with the longer duration of detention where the deepest carbon diffusion occurs at 6-hour containment with variations of $70 \%$ C - 30\% shellfish powder.
\end{abstract}

Keywords: Pack Carburizing; Catalisator; Bucket teeth; Hardness; Shellfish

\section{Abstrak}

Pada ekskavator, bagian ujung dari bucket yang berperan seperti cakar-cakar disebut bucket teeth. Bucket teeth merupakan salah satu bagian yang paling mungkin terjadi kegagalan ketika excavator digunakan. Untuk mengatasi kegagalan, dilakukan peningkatan sifat mekanis terutama nilai kekerasan dengan cara pack carburizing. Pack carburizing merupakan salah satu jenis dari carburizing dimana proses ini merupakan proses pengerasan pada permukaan (surface hardening) dengan cara menambahkan unsur karbon dengan cara difusi yang dilakukan pada suhu $950^{\circ} \mathrm{C}$ dengan variasi waktu penahanan 2,4 dan 6 jam ditambah dengan variasi serbuk cangkang kerang yang berperan sebagai energizer sebesar 30\%, 40\% dan 50\%. Setelah dilakukan pack carburizing, bucket teeth dilakukan proses quenching dengan media oli SAE 20W-50 untuk meningkatkan nilai kekerasan. Setelah itu dilakukan proses pengujian kekerasan, mikrografi, dan uji komposisi kimia untuk membandingkan material setelah dan sebelum proses pack carburizing. Hasil menunjukkan bahwa terjadi kenaikan nilai kekerasan seiring dengan banyaknya karbon dan waktu tahan, dimana kekerasan tertinggi terjadi pada variasi $70 \%$ Charcoal - 30\% serbuk cangkang kerang dengan waktu penahanan 4 jam sebesar 84.9 HRA. Unsur karbon yang terdifusi ke dalam material akan meningkat seiring penahanan waktu yang semakin lama dimana difusi karbon paling dalam terjadi pada penahanan 6 jam dengan variasi $70 \% \mathrm{C}$ - $30 \%$ serbuk cangkang kerang.

Kata kunci: Pack Carburizing, Katalisator, Bucket teeth.

\section{Pendahuluan}

Dengan semakin meningkatnya pembangunan yang ada di Indonesia saat ini, dibutuhkan alat-alat berat (heavy equipment) yang memadai guna menyokong pembangunan yang ada. Salah satu contoh alat berat yang dipakai adalah excavator. Alat berat ini sering digunakan untuk melakukan berbagai pekerjaan berat, seperti membongkar aspal, menggali tanah dan juga digunakan di dunia pertambangan sebagai alat utama untuk menggali pit.

Pada ekskavator, bagian yang digunakan sebagai alat penggali dan pengangkat material disebut sebagai excavator bucket. Bagian ujung dari bucket ini yang berperan seperti cakar-cakar disebut bucket teeth, merupakan bagian yang paling mungkin mengalami gagal (aus maupun patah) ketika ekskavator dioperasikan. Hal ini bisa terjadi karena karakteristik material yang dipakai kurang baik sehingga kurang mendukung kerja dari ekskavator. Material bucket teeth yang biasa digunakan adalah mild carbon steel dengan kandungan C sekitar $0.33 \%-0.50 \%$ sehingga dirasa material tersebut kurang mampu untuk menahan pembebanan dan kerasnya material yang dibebankan pada gigi 
excavator tersebut sehingga menyebabkan kegagalan pada material [1]. Untuk mengatasi masalah tersebut dilakukan proses pack carburizing untuk meningkatkan nilai kekerasannya dengan ditambahkan variasi serbuk cangkang kerang yang berfungsi sebagai energizer. Penggunaan cangkang kerang sebagai energizer sendiri dilakukan untuk mencari alternatif energizer lain yang sudah banyak digunakan seperti tulang sapi,arang kayu jati dan lainnya.

Tujuan dari penelitian ini adalah mengetahui pengaruh temperatur dan waktu terhadap peningkatan sifat mekanis terutama nilai kekerasan pada bucket teeth excavator selain itu didapatkan data hasil kekerasan, struktur mikro dan uji komposisi setelah dilakukan proses pack carburizing dalam rangka meningkatkan sifat mekanis bucket teeth tersebut. Dan setelah didapatkan hasil pengujian, akan dilakukan perbandingan sifat fisis dan sifat mekanis dari bucket teeth excavator hasil proses heat treatment pack carburizing dan yang belum dilakukan proses heat treatment.

\section{Material dan Metodologi}

\subsection{Metodologi}

Metode yang digunakan dalam penelitian ini adalah metode eksperimen. Metode eksperimen ini meliputi pengambilan data dengan cara pengujian, dilakukan analisa data setelah dilakukan pengujian dimana pengujian yang dilakukan adalah pack carburizing yang kemudian dilakukan pengujian kekerasan,mikrografi dan pengujian komposisi kimia. Pengujian sendiri dilakukan di 2 tempat yaitu di laboratorium metalurgi fisik teknik mesin Undip dan pengujian komposisi kimia di CV. Prima Logam, Tegal. Diagram alir penelitian dapat dilihat di Gambar 1.

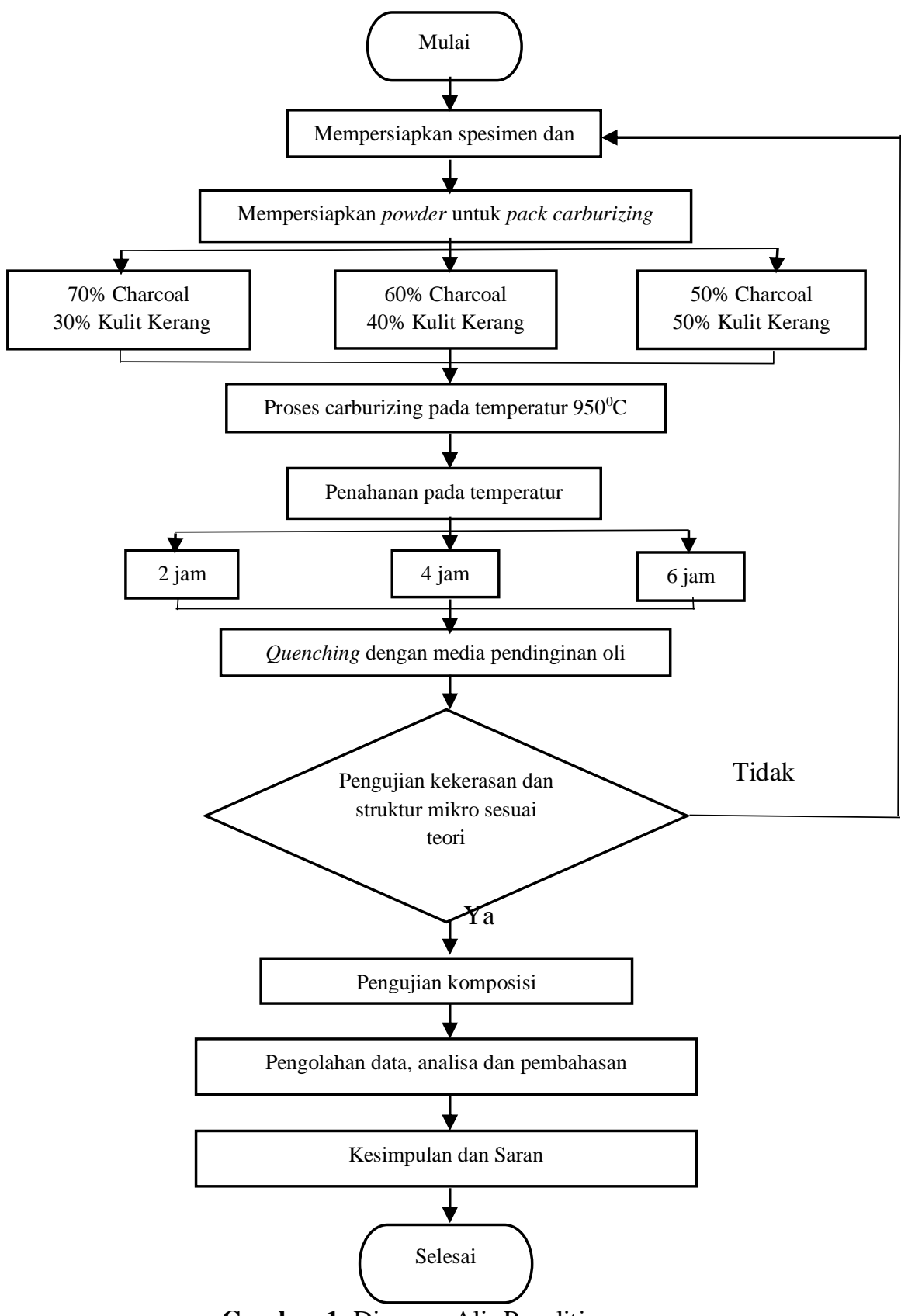

Gambar 1. Diagram Alir Penelitian 


\subsection{Material}

Penelitian ini menggunakan material jenis baja karbon rendah dimana kandungan karbon yang ada sebesar $0.33 \%$. Baja sendiri dikelompok kan menjadi 3 jenis berdasarkan kandungan karbonnya, yaitu baja karbon rendah (low carbon steel) yang memiliki kandungan karbon kurang dari $0.30 \%$ dan memiliki sifat kekerasan yang rendah namun memiliki keuletan yang tinggi. Kemudian baja karbon menengah (medium carbon steel) yang memiliki kandungan karbon sebesar 0.31-0.59\% memiliki sifat mekanis yang lebih tinggi dibandingan dengan baja karbon rendah, penggunaan baja karbon menengah biasa digunakan untuk pembuatan poros, roda gigi dan komponen mesin lainnya dan baja karbon tinggi (high carbon steel) yang memiliki kandungan karbon sebesar $0.60 \%-1.40 \%$ serta nilai kekerasan yang tinggi namun tidak ulet. Pada Gambar 2 ditunjukkan material yang digunakan dalam proses pengujian.

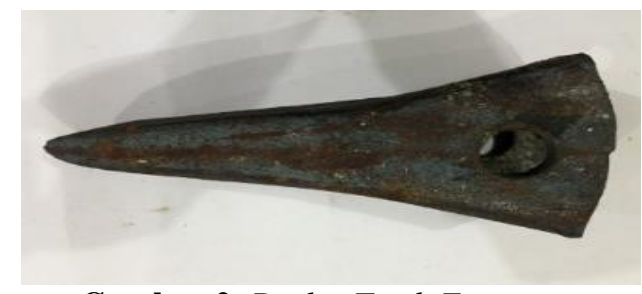

Gambar 2. Bucket Teeth Excavator

Proses pemanasan (Heat Treatment) yang digunakan menggunakan metode carburizig dengan jenis pack carburizing. Dimana Carburizing adalah salah satu case hardening yang dilakukan dengan menambahkan karbon ke permukaan material (baja karbon rendah, baik dengan atau tanpa unsur-unsur paduan. Material dipanaskan sambil berkontak dengan karbon (dalam wujud padat, gas atau cair) hingga temperatur di atas $\mathrm{A}_{3}$ (pada Gambar 3), lalu ditahan pada temperatur tersebut, kemudian didinginkan [2].

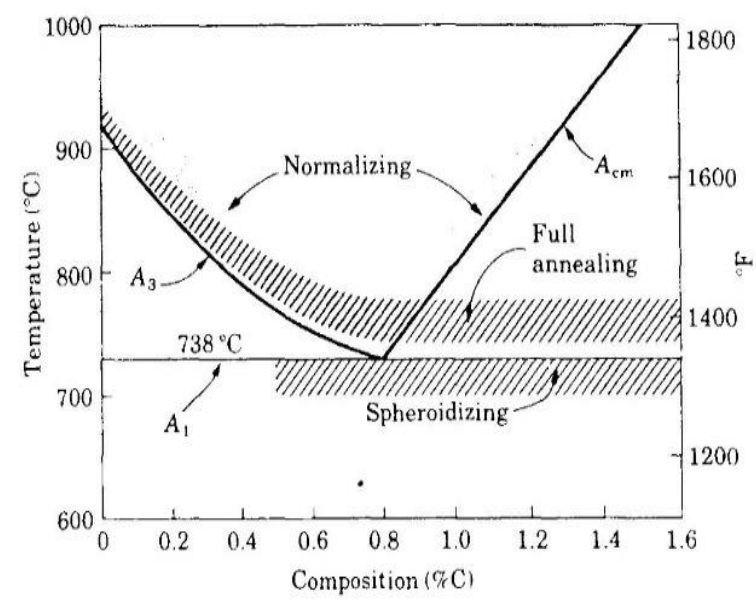

Gambar 3. Temperature Ranges untuk pemanasan baja karbon [2]

Pack carburizing adalah proses dimana karbon monoksida didapatkan dari penguraian campuran bubuk pack carburizing yang terjadi pada permukaan logam. Karbon yang baru terurai dan karbon dioksida langsung bereaksi dengan material yang disertakan pada pack carburizing untuk mendapatkan karbon monoksida yang baru.

Reaksi yang terjadi pada proses carburizing adalah reaksi karbon dengan udara menjadi karbon dioksida (Pers. 1)

$$
\mathrm{C}+\mathrm{O}_{2} \rightarrow \mathrm{CO}_{2}
$$

dan dilanjutkan dengan reaksi kembali menjadi karbon monoksida (Pers. 2).

$$
\mathrm{CO}_{2}+\mathrm{C} \rightarrow 2 \mathrm{CO}
$$

Karbon monoksida kemudian berkontak dengan permukaan dari baja dan terjadi proses difusi karbon pada material tersebut (Pers. 3).

$$
2 \mathrm{CO} \rightarrow[\mathrm{C}]+\mathrm{CO}_{2}
$$

Pembentukan karbon monoksida dibantu oleh energizer atau katalisator, seperti barium carbonate (BaCO3), calcium carbonate $(\mathrm{CaCO})$, potassium carbonate $\left(\mathrm{K}_{2} \mathrm{CO}_{3}\right)$, dan sodium carbonate $\left(\mathrm{Na}_{2} \mathrm{CO}_{3}\right)$, yang ditambahkan pada 
campuran bubuk pack carburizing. Untuk gambar skematik tentang sistem pack carburizing yang dilakukan pada penelitian adalah seperti yang ditunjukkan pada Gambar 4.

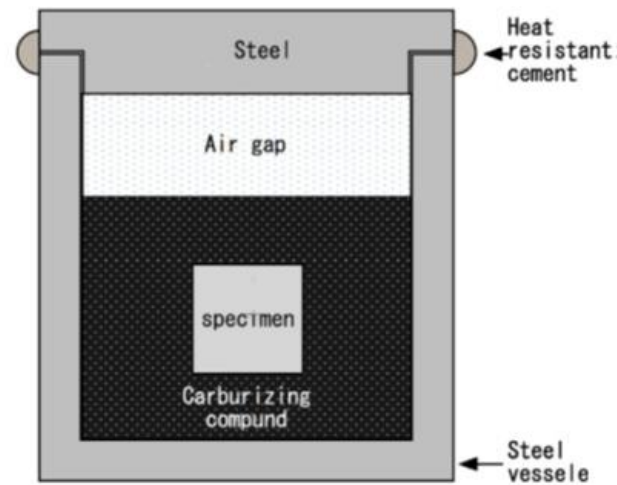

Gambar 4. Skema sistem pack carburizing [3]

Pada pack carburizing salah satu bahan yang penting adalah serbuk charcoal atau arang. Serbuk charcoal didapatkan dari arang yang telah ditumbuk dan kemudian di saring menggunakan mesh 100, Charcoal ini digunakan sebagai sumber utama dari carbon saat proses carburizing. Charcoal yang digunakan adalah seperti pada Gambar 5 dibawah.

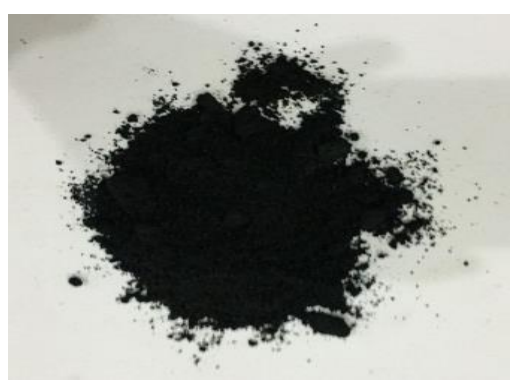

Gambar 5.Serbuk charcoal.

Selain itu energizer yang digunakan adalah serbuk cangkang kerang yang didapatkan dari tumbukan kulit kerang yang sudah dikeringkan sebelumnya. Fungsi dari kulit kerang ini adalah sebagai katalisator untuk mempercepat proses difusi karbon, selain calcium carbonate, juga bisa digunakan katalisator jenis lain yaitu barium carbonate (BaCO3), potassium carbonate (K2CO3), dan sodium carbonate (Na2CO3) [4]. Serbuk kerang yang di gunakan sebagai katalisator ditunjukkan pada Gambar 6 dibawah ini.

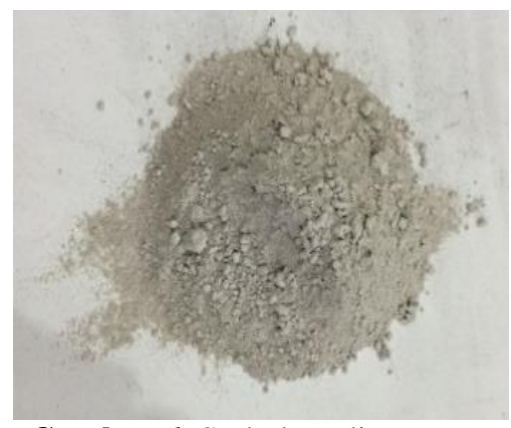

Gambar 6. Serbuk Kulit Kerang

\section{Hasil dan Pembahasan}

3.1 Pengujian Kekerasan

Pengujian kekerasan pada penelitian ini dilakukan dengan menggunakan alat uji kekerasan Rockwell Hardness Tester Model HR-150A dengan menggunakan skala A (HRA). Dengan pembebanan 60 kgf dan menggunakan penentrator intan. Mengikuti standar ASTM E-18.

Pada Tabel 1 dapat dilihat nilai kekerasan awal dari material bucket teeth yang jauh dari nilai SNI yang diinginkan. Nilai rata-rata dari spesimen awal sebesar 62 HRA masih jauh dari nilai SNI sebesar 70.4 HRA oleh karena itu dilakukan proses carburizing untuk meningkatkan kekerasannya kemudian dilakukan quenching dengan media oli SAE 20W-50 dimana hasil pengujian dapat dilihat pada Tabel 2 dan grafik dari hasil pengujian dapat dilihat pada Gambar 7. 
Tabel 1. Perbandingan Spesimen awal dengan standar SNI

\begin{tabular}{|c|c|c|c|c|}
\hline \multirow{2}{*}{ No } & \multicolumn{2}{|c|}{ SPESIMEN AWAL } & \multicolumn{2}{c|}{ SNI } \\
\cline { 2 - 3 } & (HRC) & (HRA) & \multirow{2}{*}{ (HRA) } \\
\hline 1 & 23 & 62 & \multirow{2}{*}{70} & \\
\hline 2 & 21 & 61 & & \\
\hline 3 & 23 & 62 & & \\
\hline 4 & 25 & 63 & 60.4 \\
\hline 5 & 23 & 62 & 40 & 70.4 \\
\hline Rata-rata & 23 & 62 & \\
\hline
\end{tabular}

Hasil nilai kekerasan dengan memvariasikan konsentrasi charcoal dengan serbuk cangkang kerang dan variasi penahanan temperatur menunjukkan bahwa terjadi peningkatan yang signifikan dari material awal yaitu $62.0 \mathrm{HRA}$ menjadi sekitar 84 HRA dimana nilai kekerasan tertinggi terdapat pada variasi $70 \%$ charcoal - $30 \%$ serbuk cangkang kerang sebesar 84.9 HRA.

Tabel 2. Hasil Pengujian Kekerasan bucket teeth specimen (Skala HRA) setelah di carburizing

\begin{tabular}{|c|c|c|c|c|c|c|c|c|c|c|}
\hline \multirow{7}{*}{ Oli } & Raw Material & \multicolumn{3}{|c|}{2 jam } & \multicolumn{3}{|c|}{ 4 Jam } & \multicolumn{3}{|c|}{6 jam } \\
\hline & $100-0$ & $50-50$ & $60-40$ & $70-30$ & $50-50$ & $60-40$ & $70-30$ & $50-50$ & $60-40$ & $70-30$ \\
\hline & 62 & 84.5 & 84 & 84 & 84 & 84 & 86 & 82.5 & 84 & 81.5 \\
\hline & 61 & 85 & 84 & 84.5 & 83.5 & 84 & 84.5 & 83 & 83 & 82 \\
\hline & 63 & 83 & 84.5 & 84.5 & 84.5 & 84.5 & 85 & 83.5 & 84 & 83 \\
\hline & 62 & 83.5 & 84 & 84.5 & 84 & 84.5 & 85 & 82 & 83 & 81 \\
\hline & 62 & 83 & 84.5 & 84.5 & 84 & 84 & 84 & 83 & 83 & 82 \\
\hline Rata-rata & 62 & 83.8 & 84.2 & 84.4 & 84 & 84.2 & 84.9 & 82.8 & 83.4 & 81.9 \\
\hline
\end{tabular}

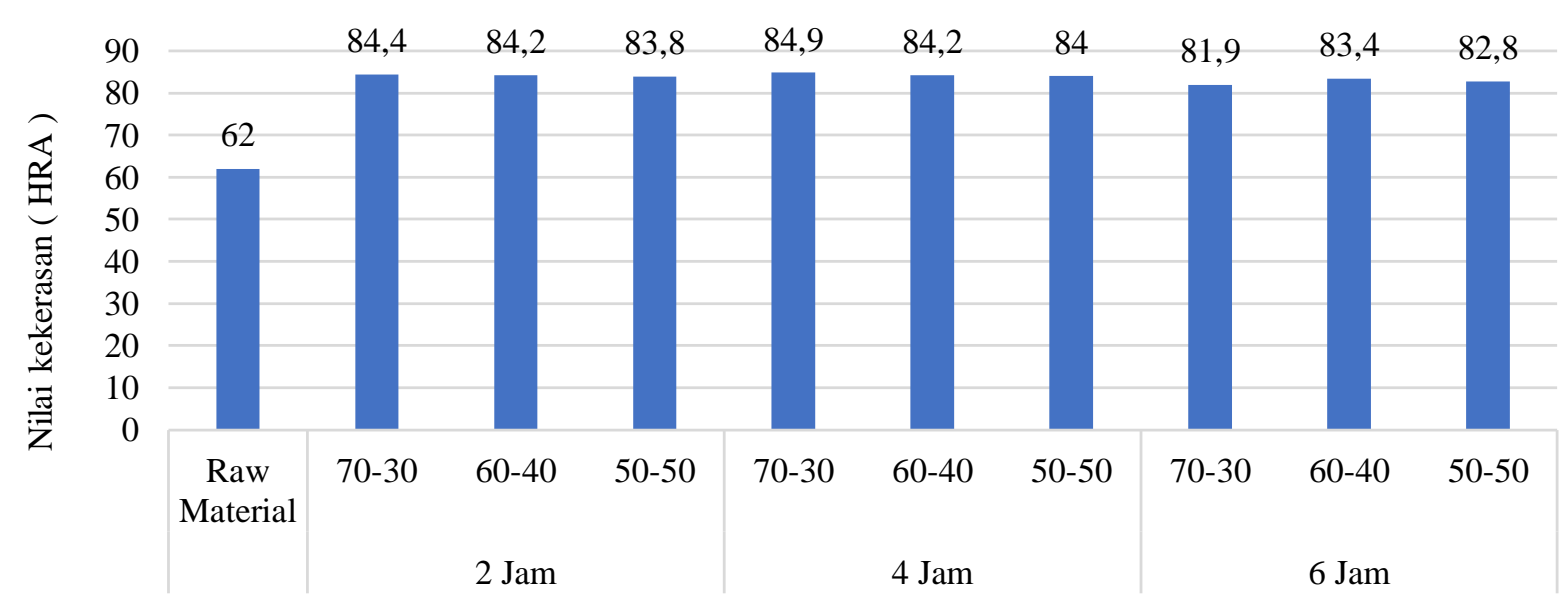

Gambar 7. Nilai kekerasan hasil carburizing dengan variasi konsentrasi charcoal dan variasi penahanan temperatur.

\subsection{Pengujian Struktur Mikro}

Berikut ini pada Gambar 8(a) dan 8(b) adalah struktur mikro material awal sebelum carburizing. Pada pengujian struktur mikro ini dilakukan menggunakan mikroskop optik.

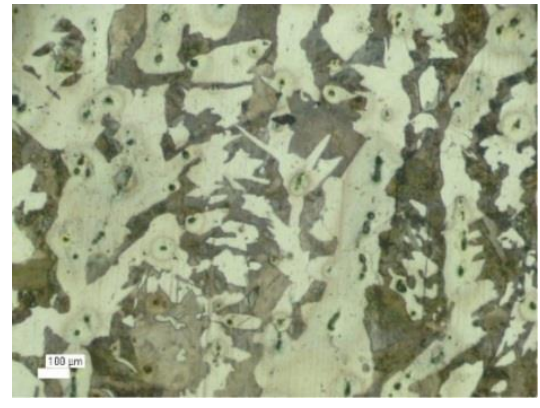

(a)

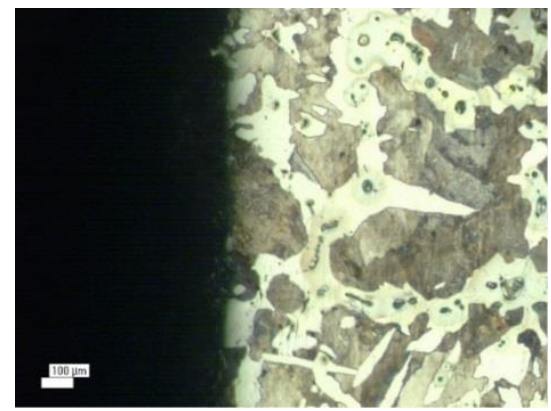

(b)

Gambar 8. (a) Struktur mikro material awal sebelum proses carburizing, (b) Struktur material awal pada bagian pinggir (case). 
Pada suatu struktur mikro material awal memiliki fasa pembentuk ferrite dan pearlite [5] seperti yang ditunjukkan pada Gambar 10. Setelah proses carburizing, terdapat perbedaan struktur mikro pada material. Dimana struktur yang terbentuk merupakan martensit. Struktur mikro berubah dikarenakan terjadinya peningkatan kadar karbon yang berpengaruh terhadap kekerasan pada material. Dapat dilihat pada Gambar 11, terlihat perbedaan warna dari material hasil carburzing. Warna yang lebih gelap menandakan kadar karbon yang ada pada pinggir material lebih banyak dibandingkan di bagian tengah yang tidak terkena difusi dari proses carburizing.

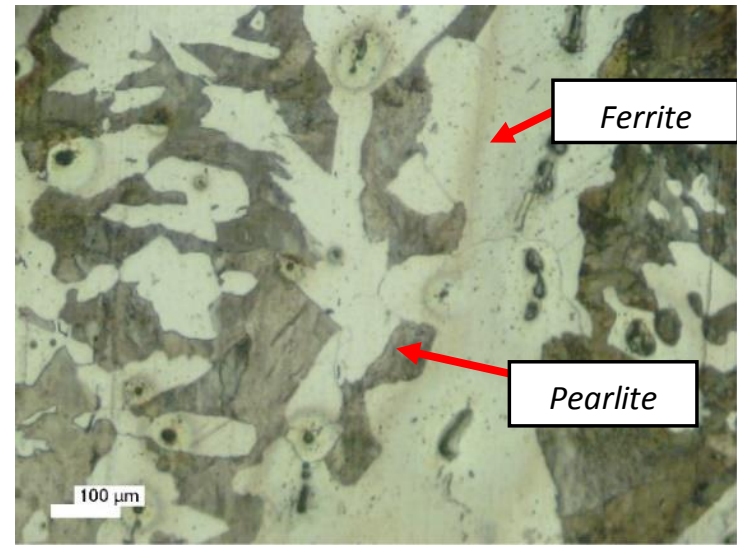

Gambar 10. Struktur mikro material awal sebelum proses carburizing

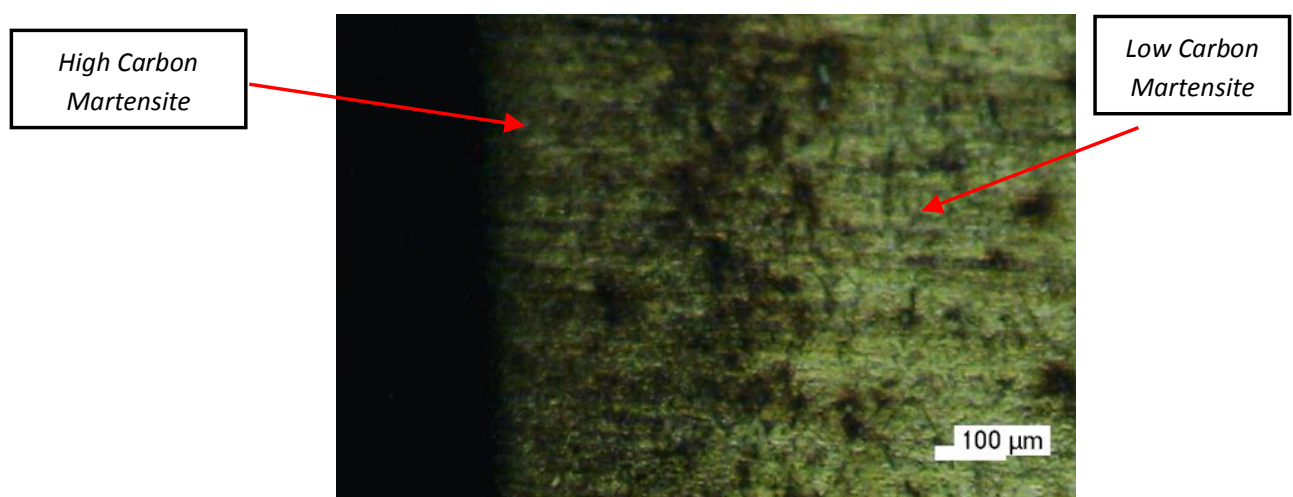

Gambar 11. Struktur mikro martensit terbentuk pada tepi material bucket teeth.

Dengan mengkarakteriasasi perbedaan high carbon martensite dengan low carbon martensite kita dapat mengetahui kedalaman penetrasi karbon yang terjadi sebagai hasil dari proses carburizing. Pada Gambar 12 dapat dilihat kedalaman difusi karbon pada material dengan berbagai variasi yang ada. Kedalaman difusi paling panjang terjadi pada variasi penahanan waktu 6 jam dengan konsentrasi charcoal sebanyak 70\%

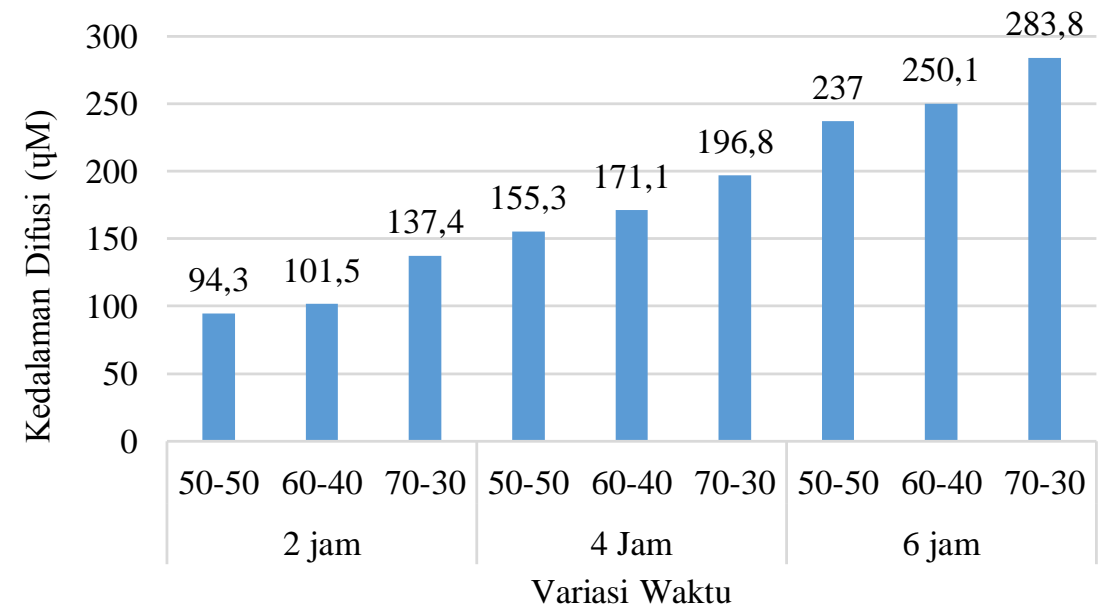

Gambar 12. Difusi karbon material baja setelah carburizing 


\subsection{Pengujian Komposisi Kimia}

Pengujian komposisi kimia bertujuan untuk mengetahui komposisi kimia yang menyusun material tersebut, terutama kadar karbon dari spesimen setelah carburizing. Dapat dilihat pada Tabel 3 kadar carbon yang terdifusi berdasarkan pengujian komposisi kimia menggunakan ARL Optic Emission Spectrometer Switzerland QTD - 127.

Tabel 3. Data hasil uji komposisi material.

\begin{tabular}{|c|c|c|c|c|c|c|c|c|c|c|}
\hline \multirow{2}{*}{ Unsur } & \multirow{2}{*}{ Raw Material } & \multicolumn{3}{|c|}{2 jam (\%) } & \multicolumn{3}{c|}{4 Jam (\%) } & \multicolumn{3}{c|}{6 jam (\%) } \\
\cline { 3 - 12 } & $50-50$ & $60-40$ & $70-30$ & $50-50$ & $60-40$ & $70-30$ & $50-50$ & $60-40$ & $70-30$ \\
\hline $\mathrm{C}$ & 0.329 & 0.475 & 0.485 & 0.495 & 0.518 & 0.584 & 0.595 & 0.624 & 0.545 & 0.665 \\
\hline $\mathrm{Si}$ & 0.308 & 1.052 & 1.077 & 1.097 & 1.100 & 1.039 & 1.097 & 1.098 & 1.077 & 1.060 \\
\hline $\mathrm{Mn}$ & 0.727 & 0.469 & 0.493 & 0.503 & 0.486 & 0.465 & 0.483 & 0.489 & 0.473 & 0.482 \\
\hline $\mathrm{P}$ & 0.007 & 0.160 & 0.150 & 0.153 & 0.134 & 0.135 & 0.147 & 0.135 & 0.127 & 0.111 \\
\hline $\mathrm{S}$ & 0 & 0 & 0 & 0 & 0 & 0 & 0 & 0 & 0 & 0 \\
\hline
\end{tabular}

Dari tabel dapat dilihat bahwa terjadi peningkatan kadar karbon setelah dilakukan proses carburizing. Kadar karbon tertinggi di dapat ketika variasi penahanan 6 jam dengan variasi 70\% charcoal - 30\% serbuk cangkang kerang. Pada Gambar 13 di tampilkan dalam bentuk grafik hasil pengujian kadar karbon hasil carburizing.

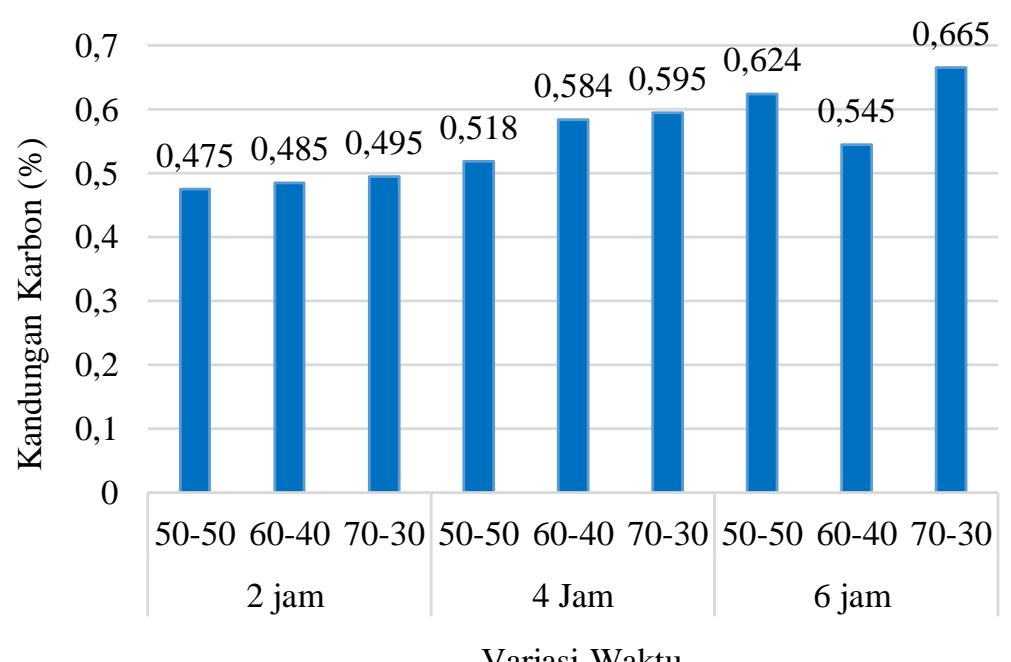

Gambar 13. Persen komposisi karbon pada permukaan material setelah carburizing.

\section{Kesimpulan}

Perlakuan carburizing yang telah dilakukan pada baja bucket teeth excavator telah berhasil. Percobaan ini dapat meningkatkan sifat mekanis dari material baja tersebut, terutama untuk nilai kekerasan yang awalnya hanya 62 HRA menjadi sekitar 84.9 HRA pada variasi 70\% charcoal-30\% serbuk cangkang kerang pada penahanan 4 jam. Selain itu terjadi peningkatan nilai kekerasan seiring dengan komposisi karbon yang bertambah di setiap variasinya. Komposisi yang paling optimal untuk mendapatkan kekerasan yang paling tinggi adalah komposisi $70 \%$ Charcoal dengan $30 \%$ serbuk cangkang kerang. Dari struktur mikro sendiri terjadi perubahan fasa, dimana fasa awal adalah fasa ferrite dan pearlite setelah mengalami proses heat treatment,fasa menjadi martensite. Pada permukaan benda uji yang telah mengalami proses carburizing, terdapat perbedaan warna dari bagian luar dengan bagian dalam dimana pada bagian luar lebih gelap warnanya. Hal ini disebabkan karena terjadinya difusi karbon dan akan meningkatkan komposisi karbon pada permukaan bagian luar benda uji.

\section{Referensi}

[1] Callister, W., Rethwisch, D., 2007, "Materials science and engineering: An introduction", $7^{\text {th }}$ Edition, New Jersey: John Wiley \& Sons, Inc

[2] Edenhofer, B., dkk, 2015, "Carburizing of steels", Woodhead Publishing Limited

[3] Bailey, R., Sun,Y., 2015, "Pack carburisation of commercially pure titanium with limited oxygen diffusion for improved tribological properties," Surf. Coatings Technol., vol. 261, pp. 28-34.

[4] Foreman, R., 2001, "Heat Treating," ASM Int, vol. 4, p. 749.

[5] Voort, V., Baldwin, W., 2004, “Metallography and Microstructures Handbook,” ASM Int., vol. 9, p. 2733. 